\title{
PROPOSTAS NORMATIVAS VOLTADAS À PROMOÇÃO DA IGUALDADE MATERIAL DE GÊNERO NO DIREITO PROCESSUAL CIVIL BRASILEIRO ${ }^{1}$
}

\section{NORMATIVE PROPOSALS AIMED AT PROMOTING GENDER EQUALITY IN BRAZILIAN CIVIL PROCEDURE}

Flávia Pereira Hill

Doutora e mestre em Direito Processual da Uerj. Professora Adjunta de Direito Processual Civil da Uerj. Pesquisadora visitante da Universidade de Turim, Itália. Tabeliã. Rio de Janeiro/RJ. E-mail: flaviapereirahill@gmail.com.

Cristina Reindolff da Motta Advogada. Doutora em Direito pela Unisinos. Mestre e Especialista em Direito Processual Civil pela Puc-RS. Diretora Regional do IBDP-RS. Membro da Coordenação Geral do Projeto Mulheres no Processo do IBDP. Porto Alegre/RS.Email: cristinamotta@camposea.adv.br

Janaína Soares Noleto Castelo Branco Doutora em Direito pela UFC. Professora Adjunta de Processo Civil da UFC. Procuradora Federal. Membro do IBDP, da Annep, da Processualistas e do Elas no Processo. Fortaleza/CE. E-mail: janainanoleto2014@gmail.com

América Cardoso Barreto Lima Nejaim Doutoranda em Direito pela UFBA. Mestre em Direito pela Universidade Estácio de Sá. Advogada Militante. Professora de Graduação e Pós-graduação. Membro da Associação

\footnotetext{
${ }^{1}$ Artigo recebido em 23/08/2021, sob dispensa de revisão.
} 
Internacional de Direito de Seguro (AIDA). Membro do IBDP. Parecerista da REDP da Uerj. Teresina/PI.

Ana Luisa Sénéchal de Goffredo Guerra Mestranda em Finanças Públicas, Tributação e Desenvolvimento pela Uerj. Especialista em Direito Processual Civil pela Ucam. Graduada em Direito pela PucRJ. Procuradora do Município de Goiânia. Goiânia/GO. Email analuisasenechal@gmail.com.

André Luna de Alencar Filho Graduado pela Universidade Federal do Ceará - UFC. Pósgraduado em Direito Notarial e Registral pela UniAmérica. Servidor Público do Tribunal de Justiça do Estado do Ceará. Fortaleza/CE.

Beatriz da Rocha Teixeira Graduanda em Direito pela UFRRJ. Participante da $3^{\mathrm{a}}$ edição do Afilhada Acadêmica do Projeto Mulheres no Processo do IBDP. Integrante do Grupo de Pesquisa Diálogos (UFRRJ) sobre Epistemologias Feministas e Direito. Estagiária da Procuradoria Geral do Estado do Rio de Janeiro. Rio de Janeiro/RJ.

Bruna Bessa de Medeiros

Advogada. Pós-graduada em direito processual civil pela Pontifícia Universidade Católica do Rio Grande do Sul. Porto Alegre/RS E-mail brunabmedeiros@outlook.com. 
Especialista em Direito Processual Civil. Coordenadora do curso de Direito e do Núcleo de Prática Jurídica do Centro Universitário Anhanguera - Leme/SP. Professora do Centro Universitário Anhanguera e da Escola Superior de Advocacia da OAB/SP. Advogada. Leme/SP.

Dara Offrede Machado Graduanda em Direito pela Uerj. Estagiária na área de Contencioso Cível no Schmidt Lourenço \& Kingston Advogados. Negociadora titular do Núcleo de Negociação da Uerj. Diretora do Comitê de Jovens Arbitralistas. Rio de Janeiro/RJ.

Débora de Paula Aprígio Bacharel em Direito, aprovada no XXXI Exame de Ordem Unificado - OAB e Pós-graduanda em Direito Público e Privado pela Escola da Magistratura do Estado do Rio de Janeiro (EMERJ). Rio de Janeiro/RJ. E-mail deboraprigio@gmail.com.

Eloísa Porto Corrêa Allevato Braem Doutora em Letras Vernáculas pela UFRJ. Pós-doutorado em Literatura Comparada pela Uerj. Graduanda em Direito pela Uerj. Professora adjunta da Uerj/FFP. Coordenadora do Grupo de Pesquisa da Uerj de Literaturas, Artes Visuais e Formação de Professores. Rio de Janeiro/RJ.

Gabriela Bonfim Barroso Pacheco dos Santos Advogada. Pós-graduanda em direito processual civil pela Universidade Cândido Mendes - Escola Superior de 
Advocacia Nacional da OAB. E-mail

gabrielabonfim96@gmail.com.

Guilherme Rodrigues de Andrade Juiz de Direito do Estado do Rio de Janeiro. Mestrando em Direito Processual pela UERJ. Pós-graduado em Direito Público e Privado pela Emerj. Rio de Janeiro/RJ.

Gustavo de Assis Souza Mestrando em Direito, Estado e Constituição pela UnB. Bacharel em Direito pela Uni-Goiás. Coordenador do Grupo de Estudos Pesquisa Constituição, Democracia e Direitos Fundamentais. Membro da Rede para o Constitucionalismo Democrático Latino-Americano e da Associação Ibero Americana de Direito e Inteligência Artificial (AID-IA). Brasília/DF.

Isabelle Oglouyan de Campos

Advogada. Bacharel em Direito pela Universidade de São Paulo com intercâmbio acadêmico pela Université Paris 1 Panthéon-Sorbonne. São Paulo/SP. E-mail isabelle.ocampos@gmail.com.

Julia Amaral Jangutta Mestranda em Direito Processual pela Uerj. Graduada em Direito pelo IBMEC. Rio de Janeiro/RJ.

Juliana Castelo Branco Silveira

Pós-graduanda em Direito da Propriedade Intelectual pela Puc-RJ. Especialista em Direito Processual Civil pela Unifor. 
Graduada em Direito pela UFC. Assistente no TJCE. Fortaleza/CE.

Julio Rodolfo Rodrigues

Bacharel em Direito pela Universidade de Ribeirão Preto Unaerp. Membro estudante no Grupo de Pesquisa Direitos Coletivos e sua Tutela da Universidade de Ribeirão Preto Unaerp. Articulista de artigos jurídicos, tendo cinco publicações internacionais em site periódico norte-americano pela Revista SSRN e uma publicação pela Revista Científica Integrada da Unaerp. Ribeirão Preto/SP. E-mail rodolforodriguesjulio@outlook.com.

Lisandra Souza de Araújo Bacharel em Direito pela Universidade de Taubaté - Unitau. Pós-graduanda Lato Sensu em Direito das Famílias e das Sucessões pelo IBMEC. Coordenadora adjunta do Grupo de Estudos sobre Igualdade de Gênero na UNITAU. Taubaté/SP.

Marco Aurélio Ventura Peixoto Advogado da União. Doutorando em Direito Processual pela Uerj. Mestre em Direito Público pela UFPE. Especialista em Direito Público pela UnB. Membro do IBDP e da Annep. Professor. Diretor Adjunto da Escola da AGU. Recife/PE.

\section{Marina Magalhães Lopes}

Defensora Pública do Estado do Rio de Janeiro. Mestre em Direito Processual pela Uerj. Rio de Janeiro/RJ. E-mail marinamaglopes@gmail.com. 
Graduanda em Direito pela Uerj. Estagiária da Defensoria Pública da União. Rio de Janeiro/RJ. E-mail marinaayres1@ hotmail.com.

Michele Lyra da Cunha Tostes Advogada. Doutoranda em Direito Processual pela Uerj. Mestre em Direito Processual pela Uerj. Integrante da rede pela Equidade de Gênero da Shell Brasil Petróleo Ltda., da Comissão de Arbitragem da OAB-RJ, e do Grupo de Diversidade do Comitê Brasileiro de Arbitragem - Cbar. Rio de Janeiro/RJ.

Renata Cortez Vieira Peixoto Registradora Civil e Tabeliã no Estado de Pernambuco. Doutoranda em Direito Processual pela Uerj. Mestre em Direito pela Unicap. Membro do IBDP e da Annep. Coordenadora da Pós-Graduação em Advocacia Extrajudicial do IAJUF/Unirios. Idealizadora do Elas no Processo. Recife/PE.

Rodrigo Vieira Farias Mestrando em Direito Processual Civil pela Uerj. Graduado em Direito pela Uerj. Pós-graduado em Direito Público pela Uerj. Assessor de Conselheiro no TCERJ. Advogado. Rio de Janeiro/RJ.

Stephany Vitória Alves Orgino Graduanda em Direito pela UFPR. Membra da Clínica de Acesso à Justiça e Educação nas Prisões (CAJEP) da UFPR. Estagiária no TJPR. Curitiba/PR. 
Tamires Rastoldo Fernandes Mendes

Mestranda em Direito Processual pela Uerj. Especialista em Direito e Processo do Trabalho pela Ucam. Graduada em Direito pela UFRJ. Sócia de Loureiro Maia Advogados. Rio de Janeiro/RJ. E-mail tamires.rastoldo@gmail.com.

Tatiana Paula da Cruz Doutoranda em Direito pela UnB. Mestre em Direito Processual pela Uerj. Graduada em Direito pela UFJF. Membro da Associação Brasiliense de Direito Processual Civil (ABPC). Parecerista da Revista Eletrônica de Direito Processual (REDP) da Uerj. Militar da Força Aérea Brasileira. Brasília/DF. E-mail tatianapaulacruz@gmail.com.

Thais da Silva Barbosa Mestre em Direito e Inovação pela UFJF. Graduada em Direito pela UFJF. Professora do Centro Universitário Estácio de Juiz de Fora e do Centro Universitário de Valença. Advogada. Juiz de Fora/MG.

Thiago Gomes Morani Doutorando em Direito Processual Civil pela Uerj; Mestre em Direito Público pela Estácio de Sá. Procurador-Geral do Município de Itaguaí. Itaguaí/RJ. E-mail thiago.morani@gmail.com.

Verônica da Silva Aleluia Berbert Professora de $1^{\circ}$ seguimento, advogada, pós-graduanda em Direito Processual Civil pela Uerj, especialização em Direito Civil e Comunicação pela Universidade de Coimbra. Rio de Janeiro/RJ. E-mail vevealeluia@gmail.com. 
Victória Antunes

Graduanda em Direito pela Uerj. Estagiária na Procuradoria Geral do Estado do Rio de Janeiro. Rio de Janeiro/RJ. E-mail vick.antunes.souza@gmail.com.

RESUMO: O presente trabalho apresenta propostas de lei, atos normativos e enunciados interpretativos voltados à promoção da igualdade material de gênero no Direito Processual Civil Brasileiro, elaborados pelo Grupo de Pesquisa Direito Processual e Democracia DROP do Programa de Pós-Graduação Stricto Sensu em Direito da Universidade do Estado do Rio de Janeiro, com vistas a oferecer soluções concretas para contornar a desigualdade estrutural entre mulheres e homens na atualidade.

PALAVRAS-CHAVE: igualdade material; igualdade de gênero; Direito Processual Civil; paridade de armas.

ABSTRACT: The present study presents some suggestions of Bill of Laws and Rules focused to promote gender equality in the Brazilian Legal Framework, elaborated by the Research Group in Gender Equality in Brazilian Civil Procedure of the Stricto Sensu PostGraduation Course in Law of the Rio de Janeiro State University, in order to surpass the structural inequality between men and women.

KEYWORDS: substantive due process of law; gender equality; Civil Procedure; parity of weapons.

\section{Introdução}

Igualdade é um substantivo feminino que, de acordo com o dicionário, possui o seguinte conceito: "fato de não se apresentar diferença de qualidade ou valor, ou de, numa 
comparação, mostrarem-se as mesmas proporções, dimensões, naturezas, aparências, intensidades; uniformidade; paridade; estabilidade" ${ }^{2}$.

A Constituição Federal de $1988^{3}$ prevê, no inciso I, do artigo $5^{\text {a }}$, que homens e mulheres são iguais em direitos e obrigações. O Código de Processo Civil ${ }^{4}$, por seu turno, prevê a igualdade no art. $7^{\circ}$, o qual preceitua: "é assegurada às partes paridade de tratamento em relação ao exercício de direitos e faculdades processuais, aos meios de defesa, aos ônus, aos deveres e à aplicação de sanções processuais, competindo ao juiz zelar pelo efetivo contraditório."

A igualdade de gênero transcende o conceito meramente formal de igualdade, pois, a partir do estudo de gênero e da constatação de que homem e mulher não são iguais, de fato é possível estabelecer a equidade entre homens e mulheres.

No Processo Civil, como exposto acima, a igualdade formal está positivada, mas para garantir que a igualdade alcance o seu viés material é necessário que as mulheres noticiem nos autos e apontem as situações de desequilíbrio, devendo ser propostas soluções para a equidade ${ }^{5}$.

O presente trabalho, então, observando precipuamente o contexto da vulnerabilidade da mulher (e mesmo outras figuras como idosos, deficientes e crianças) no âmbito processual, expõe algumas sugestões de textos normativos, no intuito de minimizar o problema concreto da desigualdade de gênero no Processo Civil Brasileiro.

Para fins de desenvolvimento, procurou-se dividir as proposições do trabalho em três linhas: 1) questões que possam ser decididas pelo Conselho Nacional de Justiça por meio de seus atos normativos e recomendações ou pelas Presidência ou Corregedoria dos tribunais locais; 2) enunciados interpretativos; 3) alterações legislativas em sentido estrito.

A partir dos estudos empreendidos e dos debates travados, constatou-se que cada espécie de questão, para ser eficazmente solucionada, depende do envolvimento de atores

\footnotetext{
${ }^{2}$ Dicionário online de Português. Disponível em: https://www.dicio.com.br/igualdade/. Acesso em 25/08/2021. ${ }^{3}$ REPÚBLICA FEDERATIVA DO BRASIL. Constituição da República Federativa do Brasil, de 05 de outubro de 1988. Disponível em: http://www.planalto.gov.br/ccivil_03/constituicao/constituicao.htm. Acesso em 25/08/2021.

${ }^{4}$ REPÚBLICA FEDERATIVA DO BRASIL. Código de Processo Civil, de 16 de março de 2015. Disponível em: http://www.planalto.gov.br/ccivil_03/_ato2015-2018/2015/lei/113105.htm. Acesso em 25/08/2021.

${ }^{5}$ HILL, Flávia Pereira. Uns mais iguais que outros: em busca da igualdade (material) de gênero no Processo Civil Brasileiro. Revista Eletrônica de Direito Processual - REDP, Rio de Janeiro, Ano 13, Volume 20, Número 2, p. 201-244, 2019, p. 205.
} 
institucionais diversos e, da mesma forma, devem ser objeto de medidas formalmente díspares. Dessa feita, verificou-se haver questões sensíveis que podem ser deliberadas internamente pelo Poder Judiciário, no âmbito de seu órgão administrativo maior de controle; outras que poderiam ser alcançadas no âmbito da doutrina e da jurisprudência, através da adequada interpretação de determinadas normas, sem a necessidade de edição de atos normativos em sentido estrito; e, por fim, aquelas questões que só seriam passíveis de adequada solução mediante o debate democrático e a deliberação no âmbito do processo legislativo.

Nesse sentido, longe de se pretender esgotar o tema, as pequenas contribuições existentes neste trabalho servem para introduzir a discussão e a necessidade de mudanças com fito de erradicar a desigualdade de gênero também na esfera do processo civil pátrio.

\section{Proposta de ato normativo:}

Temas: a) preferência de horário às mulheres gestantes, lactantes e acompanhadas de crianças de colo; b) extensão da lei Julia Matos às partes mulheres; c) realização de audiências em sala próxima à entrada do fórum, a requerimento da parte, em caso de gravidez e disponibilização de sala contígua à de audiência, a requerimento da parte, em caso de lactação; d) estímulo à celebração de negócio jurídico processual e de calendário processual voltados à paridade de armas e ao reequilíbrio da isonomia entre as partes homem e mulher.

\subsection{Texto proposto:}

ATO NORMATIVO N ${ }^{\circ}$, DE _ DE _ _ DE 2021.

Estabelece garantias às mulheres gestantes, lactantes e acompanhadas de crianças de colo ou crianças com deficiência, nas repartições forenses, e dá outras providências.

$\mathrm{O}[\ldots]$, no uso de suas atribuições legais e regimentais,

CONSIDERANDO o advento da Lei $\mathrm{n}^{\circ}$ 13.363, de 25 de novembro de 2016 (Lei Júlia Matos), que alterou a Lei no 8.906, de 4 de julho de 1994 (Estatuto da Advocacia), e a Lei no 13.105, de 16 de março de 2015 (Código de Processo Civil), para estipular direitos e 
garantias para a advogada gestante, lactante, adotante ou que der à luz e para o advogado que se tornar pai;

CONSIDERANDO o disposto na Lei Federal $\mathrm{n}^{\circ} 10.048$, de 8 de novembro de 2000, que assegura atendimento prioritário às pessoas com deficiência, aos idosos com idade igual ou superior a 60 (sessenta) anos, às gestantes, às lactantes, às pessoas com crianças de colo e aos obesos;

CONSIDERANDO o disposto na Lei Federal nº 8.069, de 11 de setembro de 1990 (Estatuto da Criança e do Adolescente);

CONSIDERANDO o Decreto ${ }^{\circ}$ 4.377/02, de 13 de setembro de 2002, o qual incorporou à legislação brasileira a Convenção sobre a Eliminação de Todas as Formas de Discriminação contra a Mulher;

CONSIDERANDO os artigos $1^{\circ}$ e 24, do Decreto $n^{\circ}$ 678/1992, de 22 de novembro de 1969, a Convenção Americana sobre Direitos Humanos (Pacto de São José da Costa Rica); CONSIDERANDO o artigo 4", alíneas "b", "c" e "e", da Convenção Interamericana para Prevenir, Punir e Erradicar a Violência Contra a Mulher (Decreto nº 1.973/1996);

CONSIDERANDO a situação de desigualdade material em desfavor da mulher gestante, lactante e acompanhada por criança de colo ou com deficiência, bem como que seja acompanhante de filho(a) internado(a) em unidade hospitalar, na realização de atos processuais;

CONSIDERANDO o dever de promoção do direito fundamental à igualdade, previsto no $\operatorname{artigo~} 5^{\circ}$, inciso I, da Constituição Federal, e no artigo $7^{\circ}$ do Código de Processo Civil; nos seus aspectos formal, pelo qual são vedadas as diferenciações arbitrárias e desproporcionais, e material, pelo qual deve haver oportunidades iguais, levando em conta suas condições distintas;

CONSIDERANDO a necessidade de disponibilização de instalações físicas condignas, nos Tribunais, à advogada, pública ou privada, à integrante do Ministério Público e da Defensoria Pública e às demais mulheres gestantes, lactantes e acompanhadas por crianças de colo ou crianças com deficiência;

CONSIDERANDO o disposto nos artigos 190, 191 e 139, VI do Código de Processo Civil; CONSIDERANDO a flexibilização procedimental, que rege o Processo Civil contemporâneo; 
CONSIDERANDO o baixo custo de implementação das medidas a serem recomendadas;

\section{RESOLVE:}

Art. $1^{\circ}$. Os órgãos do Poder Judiciário:

I - não poderão submeter mulheres gestantes, lactantes e acompanhadas por crianças de colo ou crianças com deficiência, a detectores de metais e aparelhos de raios X, ficando autorizada a revista pessoal, em local reservado e seguro, se demonstrada a sua necessidade, por agente de segurança do sexo feminino;

II - disponibilizarão quantidade mínima de vagas de garagem, próximas à entrada do órgão judiciário, destinadas às partes, auxiliares e testemunhas que sejam mulheres gestantes, lactantes e acompanhadas por crianças de colo ou crianças com deficiência, bem como àquelas que sejam acompanhantes de seu filho(a) internado(a) em unidade hospitalar, e aos respectivos acompanhantes, sem necessidade de prévio agendamento, para que possam comparecer em juízo;

III - disponibilizarão aos responsáveis, quando devam participar de atos judiciais, instalações condignas, tais como: banheiro familiar, fraldário e espaços destinados à amamentação, em locais acessíveis e em quantidade proporcional ao volume de pessoas que transitarem no local.

$\S 1^{\circ}$ Para fins do disposto neste ato normativo, considera-se criança com deficiência aquela que tem impedimento de longo prazo de natureza física, mental, intelectual ou sensorial, o qual, em interação com uma ou mais barreiras, pode obstruir sua participação plena e efetiva na sociedade em igualdade de condições com as demais pessoas, na forma do artigo $2^{\circ}$ da Lei Federal no 13.146, de 06 de julho de 2015 (Lei Brasileira de Inclusão da Pessoa com Deficiência - Estatuto da Pessoa com Deficiência).

$\S 2^{\circ} \mathrm{O}$ espaço a que se refere o inciso III será destinado aos responsáveis que se façam acompanhar de criança de colo ou criança com deficiência e deverá ser dotado de profissionais especializados e capacitados, de acordo com a disponibilidade, na respectiva comarca, de recursos humanos e financeiros, garantindo-se, no mínimo, espaço reservado para banheiro familiar, amamentação e fraldário, bem como: (i) água filtrada, (ii) microondas; (iii) geladeira; e (iv) ventilação adequada. 
Art. $2^{\circ}$. Os órgãos do Poder Judiciário deverão assegurar às advogadas, públicas e privadas, às integrantes do Ministério Público e da Defensoria Pública e às demais mulheres gestantes, lactantes e acompanhadas por crianças de colo ou crianças com deficiência, bem como àquelas que sejam acompanhantes de seu filho(a) internado(a) em unidade hospitalar:

I - preferência de horário nas audiências físicas ou virtuais de $1^{\circ}$ grau de jurisdição, inclusive nas sessões de Turmas Recursais e nas sessões de mediação e conciliação judiciais, nas sessões de julgamento físicas e virtuais dos Tribunais Estaduais, Federais e do Trabalho, bem como dos Tribunais Superiores, observada a ordem dos requerimentos e respeitados os demais beneficiários da Lei Federal n ${ }^{\circ} 10.048$, de 08 de novembro de 2000;

II - a faculdade da realização de atos processuais pela via eletrônica, caso a interessada manifeste a sua preferência nos autos em prazo razoável.

$\S 1^{\circ}$ Os atos judiciais em que seja necessária a presença de parte, auxiliar ou testemunha em estágio final da gravidez (a partir dos 7 meses) ou período pós-parto (até 120 dias após o parto), ficam adiados até o término dessa última condição, caso haja pedido e mediante prévia comprovação nos autos.

$\S 2^{\circ} \mathrm{Na}$ hipótese do $\S 1^{\circ}$, se urgente e inadiável, o ato deverá ser realizado por videoconferência.

$\S 3^{\circ}$ Poderá a parte, antes ou após os períodos dispostos no $\S 1^{\circ}$, solicitar ao juiz o adiamento do ato, mediante comprovação da sua necessidade.

Art. $3^{\circ}$ : Os órgãos do Poder Judiciário devem estimular a fixação de calendário processual em situações como gravidez, lactação, amamentação, licença maternidade ou paternidade, cirurgia ou doença da parte ou do(a) advogado(a) principal constituído(a), ainda que não seja o(a) único(a) a constar na procuração, inclusive mediante a realização de audiência para este fim, de modo a facilitar a plena participação das partes no processo.

Art. $4^{\text {o: }}$ : Os negócios jurídicos processuais devem igualmente ser estimulados pelos órgãos do Poder Judiciário nas hipóteses descritas no artigo anterior, devendo o juiz ser deferente à vontade manifestada pelas partes, limitando-se a analisar requisitos de validade inerentes ao negócio firmado. 
Parágrafo único. A celebração de negócio jurídico processual que constitua ou cause discriminação em razão do gênero deverá ser considerada nula por ofensa à boa-fé objetiva.

Art. $5^{\circ}$. Deve ser reservada, ao menos, uma sala próxima à entrada de cada fórum para a realização de audiências que contarem com a presença de mulheres gestantes, lactantes e acompanhadas por crianças de colo ou crianças com deficiência, bem como àquelas que sejam acompanhantes de seu filho(a) internado(a) em unidade hospitalar, seja como advogada, autora, ré, testemunha ou exerça função de auxiliar da justiça.

$\S 1^{\circ}$ A sala reservada para o fim descrito no caput deste artigo não poderá conter qualquer obstáculo físico, tais como escadas ou rampas, desde a entrada do fórum até a sua porta de entrada.

$\S 2^{\circ}$ As partes poderão indicar ao juiz a participação de mulheres gestantes, lactantes e acompanhadas por crianças de colo ou crianças com deficiência, bem como aquelas que sejam acompanhantes de seu filho(a) internado(a) em unidade hospitalar, em até 15 dias úteis antes da realização da audiência presencial, para que sala mencionada no caput seja adequadamente reservada.

$\S 3^{\circ}$ Em caso de necessidade de lactação ou amamentação, é possível se solicitar um intervalo no decorrer da audiência não superior a 1(uma) hora, que deverá ser respeitado pela autoridade responsável.

$\S 4^{\circ}$ As salas previstas no artigo $3^{\circ}$ deste ato normativo devem, preferencialmente, ser instaladas próximas aos espaços indicados no inciso III do artigo $1^{\circ}$ deste ato normativo e aos postos de atendimento médico dos Tribunais.

$\S 5^{\circ}$ A execução dos objetivos propostos no caput do artigo deve ser precedida de estudos de viabilidade técnica realizados pelos tribunais, com o intuito de aferir a possibilidade de concreção da medida.

Art. $6^{\circ}$. O presente ato normativo entra em vigor na data de sua publicação.

\subsection{Justificativa:}


A presente proposta tem o objetivo de ampliar a incidência, para todas as partes processuais, da Lei $n^{0} 13.363 / 2016$ (Lei Julia Matos), que alterou a Lei $n^{0} 8.906 / 1994$ (Estatuto da Advocacia), e a Lei n ${ }^{\circ}$ 13.105/2015 (Código de Processo Civil), para estipular direitos e garantias para a advogada gestante, lactante, adotante ou que der à luz e para o advogado que se tornar pai, em como para as partes acompanhadas de crianças de colo ou crianças com deficiência, bem como aquelas que sejam acompanhantes de seu filho(a) internado(a) em unidade hospitalar.

A igualdade entre mulheres e homens é garantida no art. $5^{\circ}$ da Constituição Federal de 1988, assim como em tratados internacionais subscritos pelo Brasil, dentre os quais a Declaração Internacional de Direitos Humanos, o Pacto de San José da Costa Rica e a Convenção Interamericana para Prevenir, Punir e Erradicar a Violência Contra a Mulher. Entretanto, ainda se faz necessária a adaptação da prática forense às especificidades e diferenciações biológicas existentes entre os gêneros.

Percebe-se que o mero reconhecimento da igualdade no plano normativo não é capaz de transformar as relações socialmente desiguais. Assim, para a concretização de uma igualdade real é essencial que se observe o indivíduo a partir de suas vulnerabilidades e necessidades específicas, fornecendo tratamento jurídico diferenciado.

Nesse sentido, a criação da Lei Julia Matos surge com a finalidade de trazer esse tratamento jurídico às mulheres advogadas, por vivenciarem uma situação de fato diferenciada, seja em razão de condições biológicas - gestação, lactância, pós-parto ou em razão de maternidade recente, com base na adoção - seja com o objetivo de garantir a igualdade e a não discriminação perante a lei, bem como alcançar tratamento mais digno e igualitário às advogadas.

Verifica-se que, apesar de configurar um avanço na luta contra a desigualdade de gênero, a Lei Julia Matos não tem sido aplicada na prática. Desse modo, se faz necessário que sejam criados meios para que as garantias positivadas em lei sejam implementadas de maneira prática.

De igual modo, a proposta pretende garantir tais direitos a todas as mulheres que estejam nas mesmas condições, quer sejam partes, testemunhas ou auxiliares da justiça.

Ademais, a proposta visa também a fomentar a celebração de negócios jurídicos processuais e de calendários processuais, com vistas a garantir a paridade de armas e o 
reequilíbrio da isonomia entre as partes (homem e mulher). De fato, já existem dispositivos no CPC que tratam da celebração do negócio jurídico processual, calendário processual, dilação de prazos processuais e alteração na ordem de produção de meios de prova. Contudo, devem ser ponderadas, inclusive, questões regionais, já que a cooperação e os negócios jurídicos processuais são institutos ainda pouco explorados e muitas vezes desconhecidos. Em regiões mais remotas, por exemplo, poderia ser mais difícil às partes e aos seus advogados compreenderem a ideia de que a criação de acordos processuais que "desequilibrem" o processo para torná-lo mais justo seja uma forma de promoção da igualdade.

Desta forma, faz-se necessário o incentivo ao negócio jurídico processual, com controle de validade a ser exercido pelo juiz, bem como a fixação de calendário processual, de modo a beneficiar ambas as partes, mas principalmente a mulher que, em geral, encontrase em desvantagem nas relações processuais perante o gênero oposto.

A proposta tem, pois, por objetivo atender à promoção da igualdade material no processo, corrigindo um dos principais fatores de desigualdade no processo, diretamente relacionados à maternidade.

A gestação, a lactação e os primeiros anos da maternidade geram grande esforço físico e mental para a mulher, mormente ao se considerar a longa espera que, muitas vezes, pode ocorrer no aguardo de realização de uma audiência ou para realizar sustentação oral.

Ao conferir preferência às gestantes, lactantes e mulheres acompanhadas por crianças de colo ou crianças com deficiência, bem como àquelas que sejam acompanhantes de seu filho(a) internado(a) em unidade hospitalar, quando da participação nesses atos processuais, o que se pretende é minorar o maior cansaço físico e psicológico que possuem em comparação a outros sujeitos processuais.

Nessa perspectiva, não se olvida que existam atos que devam ser praticados de modo urgente, razão pela qual se prevê a sua prática por videoconferência, com vistas a não comprometer a efetividade do processo.

Portanto, a medida objetiva a eficácia do tratamento prioritário já previsto em Lei, bem como o tratamento digno e humanitário às mulheres nas hipóteses descritas na proposta apresentada, como forma de amenizar eventuais transtornos trazidos por tal condição. A medida, além de defender os interesses das mulheres, ainda poderia gerar uma 
mudança de cultura e um tratamento mais humano voltado a elas. Dessa forma, garantir-seia a igualdade material entre homens e mulheres, contornando-se um fator de desequilíbrio que constitui verdadeiro obstáculo para a plena realização de atos processuais.

A medida é simples e pouco custosa ao Estado, pois, como regra, os fóruns já possuem salas próximas à entrada, ainda que não sejam destinadas a esse fim. Portanto, a implementação da medida requer, via de regra, apenas a reorganização do espaço físico existente nos Tribunais. Por fim, diante da existência de leis que assegurem os direitos das mulheres gestantes e lactantes, entendemos viável o endereçamento da questão via edição de ato normativo pelo Conselho Nacional de Justiça ou pelos tribunais locais, deixando a cada fórum a adequação das instruções às particularidades de sua estrutura física.

\section{Proposta de ato normativo:}

Tema: Atendimento online às vítimas de violência doméstica mesmo após a pandemia.

\subsection{Texto proposto:}

ATO NORMATIVO N ${ }^{\circ}$, DE _ DE _ DE 2021.

Dispõe sobre a criação de mecanismos complementares de proteção às vítimas de violência doméstica e familiar contra a mulher, idosos, crianças ou adolescentes, estabelecendo o atendimento online aos vulneráveis em situação de violência doméstica e familiar e dá outras providências.

O [...], no uso das suas atribuiçõos legais;

CONSIDERANDO a importância da elaboração de mecanismos complementares de proteção às vítimas de violência doméstica e familiar contra a mulher, idosos, crianças ou adolescentes e pessoas com deficiência,

CONSIDERANDO a gravidade atual do estado de emergência de saúde internacional, que vem afetando precipuamente os grupos de pessoas vulneráveis, aqui mencionados, pela imposição do distanciamento social;

CONSIDERANDO que a Lei 14.022/2020 dispõe sobre a necessidade de se expandir as medidas de enfrentamento à violência doméstica e familiar contra a mulher e de 
enfrentamento à violência contra crianças, adolescentes, pessoas idosas e pessoas com deficiência durante a emergência de saúde pública de importância internacional decorrente da pandemia do novo Coronavírus;

CONSIDERANDO a urgência de se estender tais mecanismos para além da pandemia, inclusive mediante a utilização de novas tecnologias com o objetivo de facilitar o acesso à justiça e a garantia a proteção da vítima;

CONSIDERANDO que tais adaptações dos procedimentos de atendimento virtual devem ser asseguradas pelo Poder Público como forma de prevenção e repressão à violência, conforme previsto na Lei 11.340/2006 e na Lei 14.022/2020;

CONSIDERANDO a necessidade de dar às vítimas de violência doméstica e familiar voz ativa na resolução dos conflitos com os agressores, tornando-as autoras da solução do problema;

CONSIDERANDO as garantias constitucionais da dignidade da pessoa humana, bem como de acesso à justiça, de direito à informação, e a necessidade de se dirimir e combater a violência doméstica e familiar em nossa sociedade;

\section{RESOLVE:}

Art. $1^{\circ}$. Fica estabelecido que as medidas adotadas pela Lei 14.022/20, visando à criação de mecanismos complementares de proteção às vítimas de violência doméstica e familiar contra mulheres, crianças, adolescentes e idosos sejam acrescidas de novos dispositivos, a fim de que os mecanismos de proteção tenham efetividade no cenário pós-pandêmico no âmbito do Poder Judiciário.

$\S 1^{\circ}$ Para o cumprimento dos fins dispostos no caput, serão disponibilizadas salas exclusivas para entrevista entre a vítima e seus(suas) defensores(as) nos fóruns ou seções judiciárias em que haja julgamento ou varas de violência doméstica.

$\S 2^{\circ}$ Nos casos em que não seja possível a disponibilização de sala própria e permanente para a entrevista entre as vítimas de violência e seus(suas) defensores(as) nos fóruns ou seções judiciárias, deve a autoridade judiciária local, previamente, disponibilizar um espaço para que o atendimento seja realizado de maneira privada, a fim de resguardar a vítima de violência até o momento da audiência; 
$\S 3^{\circ}$ As salas previstas no $\S 1^{\circ}$ devem ser acessíveis e, preferencialmente, nos andares inferiores e próximo aos banheiros, possibilitando o acesso de gestantes e pessoas com mobilidade reduzida, sejam as vítimas de violência ou os seus(suas) defensores(as).

Art. $2^{\circ}$. Sem qualquer prejuízo ao atendimento presencial humanizado às vítimas de violência doméstica, o Poder Judiciário deverá adotar medidas necessárias a garantir o atendimento virtual das pessoas em situação de violência doméstica e familiar, sem prejuízo das determinações das Leis $n^{\circ} 11.340$, de 7 de agosto de 2006 e Lei $n^{\circ} 14.022$, de 1 de julho de 2020.

$\S 1^{\circ}$ Para o cumprimento dos fins dispostos no caput, será implantado sistema eletrônico em que a vítima de violência não seja exposta a tratamento ultrajante, podendo ser ouvida, na esfera judicial, sem a presença do agressor.

$\S 2^{\circ}$ Em convênio com as polícias locais, incluindo as Delegacias de Atendimento à Mulher, serão disponibilizados totens às vítimas de violência, a fim de permitir que cada sede do Poder Judiciário configure um local seguro para a realização de qualquer denúncia de violência sofrida.

Art. $3^{\circ}$. Ficam obrigados os Tribunais de Justiça dos Estados da Federação e do Distrito Federal a designarem oficiais de justiça específicos, possibilitando a imediata e célere intimação dos agressores de qualquer ato do processo, mormente em relação às tutelas provisórias que visem à proteção da integridade das vítimas de violência doméstica e familiar.

Art. $4^{\circ}$. Ficam obrigados os Tribunais de Justiça dos Estados da Federação e do Distrito Federal a criarem Centros de Justiça Restaurativa em prol das vítimas de violência doméstica e familiar.

Art. $5^{\circ}$. As medidas devem assegurar o sigilo previsto nas Leis $n^{\circ} 12.527$, de 18 de novembro de 2011 (Lei de Acesso à Informação), 13.460, de 26 de junho de 2017, 13.709, de 14 de agosto de 2018 (Lei Geral de Proteção de Dados Pessoais) e na 14.129, de 19 de março de 2021. 
Art. $6^{\circ}$. Este ato normativo entra em vigor na data de sua publicação.

\subsection{Justificativa:}

Diante do estado de emergência de saúde mundial, decorrente da pandemia do Coronavírus, foi necessária a imposição de medidas de restrição de deslocamento, como o isolamento social. No entanto, por razões sociológicas e culturais, observou-se que o confinamento social gerou um aumento significativo de casos de violência doméstica e familiar contra mulheres, crianças, adolescentes, idosos e pessoas vulneráveis de forma geral.

De acordo com o Ministério da Mulher, da Família e dos Direitos Humanos, houve um aumento de $9 \%$ no número de ligações no canal DISQUE 180, que recebe denúncias de violência contra mulheres. Entre os dias 1 a 16 de março de 2020, foram realizadas 3.045 ligações e 829 denúncias. Já entre os dias 17 e 25 de março de 2020 esses números saltaram para 3.303 ligações e 978 denúncias, respectivamente. ${ }^{6}$

Neste sentido, foi editada a Lei $14.022 / 2020^{7}$, contemplando medidas voltadas ao enfrentamento da violência doméstica e familiar durante a pandemia. Por sua vez, a Lei 13.979/2020 ${ }^{8}$ prevê que os serviços de atendimento a essas pessoas são considerados essenciais e ratifica quem são essas pessoas, notadamente as mulheres em situação de violência doméstica e familiar, crianças e adolescentes vítimas de crimes previstos no Estatuto da Criança e do Adolescente ou no Código Penal, pessoas idosas vítimas de crimes previstos no Estatuto do Idoso ou no Código Penal, e pessoas com deficiência vítimas dos crimes previstos no Estatuto da Pessoa com Deficiência ou no Código Penal.

Por todo exposto, propõe-se que o presente ato normativo, ratificando o disposto nas referidas leis, crie mecanismos adequados, práticos e eficazes que sirvam de garantia para a proteção aos vulneráveis não somente no momento pandêmico, mas para além dele,

\footnotetext{
${ }^{6}$ Disponivel em https://www.gov.br/mdh/pt-br/assuntos/noticias/2020-2/marco/coronavirus-sobe-o-numerode-ligacoes-para-canal-de-denuncia-de-violencia-domestica-na-quarentena. Acesso em 25/08/2021.

${ }^{7}$ http://www.planalto.gov.br/ccivil_03/_ato2019-2022/2020/lei/L14022.htm. Acesso em 25/08/2021.

${ }^{8}$ http://www.planalto.gov.br/ccivil_03/_ato2019-2022/2020/lei/113979.htm. Acesso em 25/08/2021.
} 
de forma que o Poder Público perenize as benfazejas medidas protetivas virtuais e presenciais em âmbito Nacional, para facilitar o efetivo acesso à justiça.

\section{Proposta de recomendação do Conselho Nacional de Justiça}

Tema: Dispensa da realização da sessão de mediação nas ações de família, a requerimento da parte, em caso de violência doméstica.

\subsection{Texto proposto:}

RECOMENDAÇÃO N _, DE _ DE MAIO DE 2021.

Recomenda aos Tribunais e magistrados a dispensa da realização de sessão de conciliação e mediação nas ações de família quando figurar como parte vítima de violência doméstica e familiar.

O [...], no uso de suas atribuições legais e regimentais;

CONSIDERANDO ser objetivo fundamental da República Federativa do Brasil a construção de uma sociedade livre, justa e solidária (artigo $3^{\circ}, \mathrm{I}$ ), através da promoção do princípio da dignidade da pessoa humana (art. $1^{\circ}$, III) e reconhecimento da igualdade entre homens e mulheres (art. $5^{\circ}$, I), vedando-se quaisquer formas de discriminação ( $\operatorname{art.} 3^{\circ}$, IV), e a necessidade de promover e garantir de forma substancial a concretização do direito fundamental à igualdade entre homens e mulheres;

CONSIDERANDO o artigo $5^{\circ}$, $\S 2^{\circ}$ da Constituição da República Federativa do Brasil de 1988, segundo o qual os direitos e garantias expressos na Constituição não excluem outros decorrentes do regime e dos princípios por ela adotados, ou dos tratados internacionais de que a República Federativa do Brasil seja parte;

CONSIDERANDO os artigos $1^{\circ}, 2^{\circ}$, alíneas "a", "c", e 15, item 2, do Decreto no 1.973 de

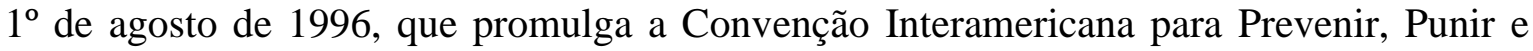
Erradicar a Violência Contra a Mulher ou "Convenção Belém do Pará";

CONSIDERANDO o artigo 24 do Decreto no 1.973/1996 - Convenção Belém do Pará, segundo o qual os Estados-Partes comprometem-se a adotar todas as medidas necessárias de âmbito nacional para alcançar a plena realização dos direitos reconhecidos nessa Convenção; 
CONSIDERANDO o Decreto ${ }^{\circ}$ 4.377/02, de 13 de setembro de 2002, o qual incorporou à legislação brasileira a Convenção sobre a Eliminação de Todas as Formas de Discriminação contra a Mulher;

CONSIDERANDO os artigos $1^{\circ}$ e 24, do Decreto n ${ }^{\circ}$ 678/1992, de 22 de novembro de 1969, a Convenção Americana sobre Direitos Humanos (Pacto de São José da Costa Rica); CONSIDERANDO as recomendações emitidas pela Comissão Interamericana de Direitos Humanos no caso 12.051, de 4 de abril de 2001;

CONSIDERANDO a Lei Federal $\mathrm{n}^{\circ}$ 11.340/06, de 7 de agosto de 2006, que criou mecanismos para coibir a violência doméstica e familiar contra a mulher, nos termos do $\$ 8^{\circ}$ do art. 226 da Constituição Federal, da Convenção sobre a Eliminação de Todas as formas de Discriminação contra as Mulheres e da Convenção Interamericana para Prevenir Punir e Erradicar a Violência contra a mulher, especialmente em seus artigos $3^{\circ}, \S 2^{\circ}$ e $7^{\circ}$, inciso II; CONSIDERANDO ser o direito de ação e acesso à justiça um direito público e subjetivo das mulheres cidadãs inseridas em uma sociedade democrática, estampado no artigo $5^{\circ}$, inciso XXXV, da Constituição Federal de 1988, segundo o qual o processo deve atingir seus fins sociais, visto que instrumento fundamental às jurisdicionadas não devendo estas, em razão de óbices procedimentais, sofrer violências;

CONSIDERANDO o Enunciado $\mathrm{n}^{\circ} 639$ de 24, 25 e 26 de março de 2017 do VIII encontro do Fórum Permanente de Processualistas Civis, segundo o qual o juiz poderá, excepcionalmente, dispensar a sessão de mediação ou conciliação nas ações de família, quando uma das partes estiver amparada por medida protetiva;

CONSIDERANDO que o Código de Processo Civil (Lei no ${ }^{\circ}$ 13.105/15) deve ser ordenado, disciplinado e interpretado conforme os valores, normas e princípios fundamentais estabelecidos tanto na Constituição da República Federativa do Brasil (art. $\left.1^{\circ}, \mathrm{CPC} / 15\right)$ como nos tratados internacionais de que esta seja parte;

CONSIDERANDO que a submissão da mulher vítima de violência doméstica, parte em processo judicial ou extrajudicial, à realização de sessão de conciliação e mediação obrigatoriamente, poderá ocasionar sobrevitimização e sofrimento às partes que se encontram em uma situação de desigualdade fática prejudicial ao exercício pleno e efetivo do seu direito de acesso à justiça, na medida em que afetados a isonomia e o equilíbrio (art. 
$2^{\circ}$, II, Lei $\left.n^{\circ} 13.140 / 2015\right)$ entre os mediandos, ante a situação de violência precedente ou atual;

CONSIDERANDO que as sessões de mediação e conciliação, previstas para as Ações de Família (arts. 693 a 699), estampadas nos artigos 696 e 697 do Código de Processo Civil (Lei $\left.n^{\circ} 13.105 / 15\right)$ e na Lei $n^{\circ} 13.140 / 2015$, objetivam a realização de acordo legítimo e consentâneo com a autonomia da vontade e o alcance da economia e da eficiência e que, nas hipóteses em que há violência doméstica e familiar, tais desideratos não seriam alcançados;

\section{RESOLVE:}

1. Recomendar aos setores de distribuição dos Tribunais de Justiça que identifiquem, com uso de tarjas e alertas nos sistemas de peticionamento eletrônico, no ato de distribuição de uma nova ação judicial, a existência de qualquer demanda prévia envolvendo violência doméstica entre as mesmas partes;

2. Recomendar aos juízos que, em casos de violência doméstica e familiar, independentemente de já ter sido ajuizada ação própria, somente seja designada a sessão de mediação ou conciliação, inclusive nas ações de família, mediante manifestação expressa da vítima requerendo a sua realização;

3. Recomendar aos juízos que, em qualquer processo judicial em que a mulher figure como ré e já exista ação em curso que verse sobre violência doméstica entre as mesmas partes, conste expressamente, no mandado de citação, o determinado no item 2 desta Recomendação;

4. Recomendar aos juízos que seja designada a sessão de mediação ou conciliação online, caso assim seja requerido pela vítima de violência doméstica e familiar, de forma a se evitar o reencontro pessoal entre vítima e agressor; e

5. Esta Recomendação produz efeitos a partir de sua publicação, sendo oportunizado o prazo de 6 (seis) meses para que os tribunais implementem estas diretrizes em seus sistemas e a repliquem nos treinamentos para servidores e terceirizados.

\subsection{Justificativa:}


Após adotada pelo Brasil a Convenção Americana de Direitos Humanos (Decreto n ${ }^{\circ}$ 678/92), conhecida como Pacto de São José da Costa Rica, e a Convenção Interamericana para Prevenir Punir e Erradicar a Violência contra a Mulher (Decreto n ${ }^{\circ} 1.973 / 96$ ), apelidada de Convenção Belém do Pará, torna-se obrigatória a observância das disposições destes tratados pelo Estado-parte, sob pena de responsabilização internacional frente às violações.

Neste cenário, vale relembrar que, em 1983, Maria da Penha Maia Fernandes foi vítima de duas tentativas de homicídio, tendo sofrido, além da violência física, violências psicológicas e morais, sendo vítima, ainda, da violência institucional praticada pelo Estado, ante a impunidade vivida por 15 anos, visto que seu agressor, mesmo após condenado no Tribunal do Júri em 4 de maio de 1991, permaneceu em liberdade, vindo a ser preso apenas no ano de 2002.

Ante a negligência e a omissão estatal, o caso foi apresentado à Comissão Interamericana de Direitos Humanos (caso 12.051), tendo sido elaborada uma recomendação por essa Comissão em 2001, na qual se reconheceu a tolerância do Estado brasileiro com a violência doméstica e familiar, condenando-o internacionalmente por negligência e omissão.

Ocorre que, como fruto deste verdadeiro diálogo das fontes nacionais e internacionais e do engajamento da sociedade civil junto aos movimentos feministas e ao governo, veio à tona a proposta de criação de medida legislativa para coibir a violência doméstica contra a mulher, tendo sido editada em 7 de agosto de 2006 a Lei n. 11.340, conhecida como Lei Maria da Penha.

Dentre as disposições dessa lei (Lei $\mathrm{n}^{\circ}$ 11.340/06), que modificou de forma significativa o ordenamento jurídico brasileiro, se prevê, como forma de violência contra as mulheres, a violência psicológica (art. $\left.7^{\circ}, \mathrm{I}\right)$, reconhecendo-se esta como “(...) qualquer conduta que lhe cause dano emocional e diminuição da autoestima (...) ou qualquer outro meio que lhe cause prejuízo à saúde psicológica e à autodeterminação". Ademais, prevê a Convenção Belém do Pará, em seu artigo $2^{\circ}$, que “(...) a violência contra a mulher abrange a violência física, sexual e psicológica. (...) c) perpetrada ou tolerada pelo Estado ou seus agentes, onde quer que ocorra.", ainda, prevê o artigo $4^{\circ}$ desta mesma Convenção que "Toda mulher tem direito ao reconhecimento, desfrute, exercício e proteção de todos os direitos e liberdades $(\ldots)$ c) direito a que se respeite sua integridade física, mental e moral”. 
Feitas tais considerações, tem-se que o Código de Processo Civil dispõe que, nas Ações de Família (arts. 693 a 699), realizar-se-á, obrigatoriamente, sessão de conciliação e mediação. Com efeito, as disposições dos artigos 696 e 697 desse diploma almejam oportunizar a solução consensual dos conflitos, privilegiando-se a economia e eficiência, na medida em que, chegando as partes a um acordo, o procedimento se findaria ali, alcançandose o ideal constitucional da duração razoável do processo, garantindo-se a celeridade da tramitação (art. $5^{\circ}$ LXXVIII).

No entanto, nem sempre, diante do caso concreto, a lei se demonstra justa ou eficaz. Por este motivo se justifica a presente Recomendação, uma vez que a legislação foi omissa quanto à hipótese na qual uma das partes é vítima de violência doméstica e familiar. Nesse cenário, entende-se que manter a realização obrigatória da audiência é o mesmo que subjugar a vítima a uma nova situação de violência (sobrevitimização), na medida em que se verá compelida a reencontrar o seu agressor no momento da sessão.

Verifica-se, ainda, que o consentimento livre e esclarecido é extremamente necessário para garantir que a vítima, ao consentir com a realização das sessões de mediação ou conciliação, entenda como elas se desdobrarão, bem como quanto às consequências e aos riscos que poderá vir a suportar. O termo de consentimento livro e esclarecido é difundido como princípio do biodireito e da bioética, mas se afigura essencial em situações como essa, em que a vítima, enquanto parte de um processo de ação de família (ou de qualquer outro que envolva violência doméstica) não necessariamente entende os procedimentos, nem o que tais sessões podem desencadear, tanto psicológica, quanto fisicamente.

Nessa perspectiva, como forma de se proteger a dignidade dessas mulheres, vítimas de violência doméstica e familiar, justifica-se a Recomendação, que pretende a flexibilização do procedimento civil, possibilitando-se a dispensa da realização da sessão de conciliação e mediação nessas hipóteses, como forma de se garantir às mulheres o acesso à justiça, através de um processo justo e efetivo, no qual não sejam novamente submetidas a uma situação de violência legitimada pelo procedimento, que não deve ser analisado pela letra fria da lei, mas sim em conjunto com os demais instrumentos que direcionam o ordenamento jurídico, dentre os quais os princípios e os tratados internacionais, interpretando-se a legislação processual em favor das mulheres em observância de suas dignidades. Nos dizeres de Flávia Hill “(...) 
nessa hipótese, a aplicação da regra, embora condiga com a igualdade formal, a todas as luzes vulnera a igualdade material de gênero". 9

Diante de todo o exposto, a Recomendação é medida para combater, como fim último, a desigualdade de gênero - ainda hoje presente no Brasil, de forma tanto sutil, como escancarada, fruto de uma sociedade patriarcal construída por valores machistas e sexistas a qual se faz presente, por vezes, na aplicação automática e acrítica de algumas disposições do Código de Processo Civil, conforme delineado anteriormente. Almeja-se, portanto, contornar o desequilíbrio entre vítima e agressor e a natural vulnerabilidade da vítima, normalmente do sexo feminino, com a mitigação da obrigatoriedade da sessão de conciliação e mediação nas Ações de Família nas hipóteses de violência doméstica e familiar. O propósito da Recomendação, portanto, é viabilizar pilares sólidos para a construção de uma sociedade com maior igualdade material de gênero a partir da construção de um processo civil mais humano e cooperativo.

\section{Proposta de Projeto de Lei e propostas de enunciados interpretativos ao Código Penal e ao Código de Processo Civil}

Tema: Cautelas na produção de provas em caso de ação envolvendo divulgação indevida de imagens íntimas (depoimento pessoal e exibição de vídeo em audiência).

\subsection{Proposta de Projeto de Lei:}

Projeto de Lei XXX, de 2021.

(Do Sr. Deputado X)

Altera a Lei n. ${ }^{\circ} 13.105$, de 16 de março de 2015 - Código de Processo Civil, e o DecretoLei n. 2.848, de 7 de dezembro de 1940 - Código Penal, e dá outras providências.

O Congresso Nacional decreta:

Art. $1^{\circ}$. A Lei n ${ }^{\circ} 13.105$, de 16 de março de 2015 (Código de Processo Civil), passa a vigorar com as seguintes alterações:

\footnotetext{
${ }^{9}$ Op. Cit., p. 221.
} 
Art. 368-A Nas ações envolvendo a divulgação não consensual de imagens íntimas, a exibição do material em audiência e a realização de prova pericial no material objeto de divulgação somente serão admitidas quando houver fundada suspeita quanto à sua autenticidade, cuja arguição deverá ser feita na forma do artigo 430 deste Código. (NR)

Art. 368-B Nas ações referidas no artigo anterior, assegura-se à parte autora tratamento diferenciado em audiência de instrução e julgamento, mediante requerimento, para a produção de provas com as seguintes cautelas:

I. depoimento fora da audiência e com a assistência de profissionais especializados, preferencialmente do mesmo sexo da parte autora;

II. reprodução de imagens e vídeos reservada, a ser assistida apenas pelo magistrado, caso este considere indispensável à formação do convencimento, sem prejuízo do acesso ao material pelos advogados, em homenagem ao contraditório. (NR)

Art. 385

(...)

$\S 4^{\circ}$ Nas ações envolvendo divulgação indevida de imagens íntimas, é admitido o depoimento da parte autora mediante seu próprio requerimento. (NR)

Art. 434

Parágrafo único. Quando o documento consistir em reprodução cinematográfica ou fonográfica, a parte deverá trazê-lo nos termos do caput, mas sua exposição será realizada em audiência, intimando-se previamente as partes, ressalvada a hipótese do art. 368-B, II. (NR)

Art. $2^{\circ}$. O Decreto-Lei n. 2.848, de 7 de dezembro de 1940, passa a vigorar com as seguintes alterações:

Art. 218-C.

(...) 
$\S 2^{\circ}$ A pena é aumentada de $1 / 3$ se o crime é praticado por funcionário público que tem acesso ao material em razão do cargo que ocupa ou por qualquer outro sujeito processual que tenha acesso em razão de sua atuação profissional. (NR)

Exclusão de ilicitude

$\S 3^{\circ}$ Não há crime quando o agente pratica as condutas descritas no caput deste artigo em publicação de natureza jornalística, científica, cultural ou acadêmica com a adoção de recurso que impossibilite a identificação da vítima, ressalvada sua prévia autorização, caso seja maior de 18 (dezoito) anos. (NR)

Art. $3^{\circ}$. Esta Lei entra em vigor na data de sua publicação.

\subsection{Propostas de Enunciados Interpretativos ao Código de Processo Civil:}

- Art. 189, III, CPC: “A divulgação não consentida de imagens íntimas justifica a tramitação em segredo de justiça, nos termos do art. 189, III, do CPC."

- Art. 388, III, CPC: “A parte não é obrigada a depor sobre fatos que digam respeito ao conteúdo de imagens íntimas do depoente que tenham sido divulgadas de forma não consensual por ofender a honra, nos termos do art. 388, III, do CPC"

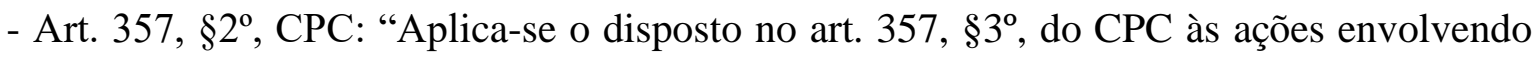
divulgação não consensual de imagens íntimas, para que, em cooperação com o juiz, as partes delimitem as questões de fato controvertidas, sobre as quais recairá a atividade probatória, especificando os meios de prova admitidos."

\subsection{Justificativa:}

As medidas apresentadas linhas acima se justificam pelo reconhecimento de que há uma perpetuação da desigualdade material de gênero dentro do processo civil no tratamento das ações decorrentes de divulgações não consensuais de imagens íntimas, em especial no momento de produção probatória. 
Há um justo e fundado receio de que, não sendo efetivamente implementada a igualdade material de gênero nestas situações, estas se manterão como desestímulo ao acesso ao Judiciário, perpetuando violências e fomentando uma deletéria litigiosidade contida.

As propostas encontram fundamento na Convenção Interamericana para prevenir, punir e erradicar a violência contra a mulher - Convenção de Belém do Pará de 1994, bem como nos direitos constitucionais à privacidade e, principalmente, dignidade da pessoa humana.

Além disso, a Convenção prevê a responsabilidade estatal para que a mulher que sofre violência não seja revitimizada ou sofra violência institucional. Faz-se necessário, portanto, inserir na legislação vigente mecanismos que protejam essas mulheres e punam aqueles que representam o Estado e violam o sigilo processual.

É importante destacar que a violência contra a mulher constitui uma violação dos direitos humanos e das liberdades fundamentais e limita total ou parcialmente à mulher o reconhecimento, gozo e exercício de tais direitos e liberdades. O vazamento de imagens íntimas afeta a sua sexualidade e pode gerar constrangimentos e sobrevitimização.

A responsabilidade dos Estados signatários está prevista no art. $7^{\circ}$ da referida Convenção, destacando-se os seguintes deveres:

a. abster-se de qualquer ação ou prática de violência contra a mulher e velar para que as autoridades, seus funcionários, pessoal e agentes e instituições públicas se comportem conforme esta obrigação; b. atuar com a devida diligência para prevenir, investigar e punir a violência contra a mulher;

c. incluir em sua legislação interna normas penais, civis e administrativas, assim como as de outra natureza que sejam necessárias para prevenir, punir e erradicar a violência contra a mulher e adotar as medidas administrativas apropriadas que venham ao caso;

d. adotar medidas jurídicas que exijam do agressor abster-se de fustigar, perseguir, intimidar, ameaçar, machucar ou pôr em perigo a vida da mulher de qualquer forma que atente contra sua integridade ou prejudique sua propriedade;

e. tomar todas as medidas apropriadas, incluindo medidas de tipo legislativo, para modificar ou abolir leis e regulamentos vigentes, ou para modificar práticas jurídicas ou consuetudinárias que respaldem a persistência ou a tolerância da violência contra a mulher; f. estabelecer procedimentos jurídicos justos e eficazes para a mulher que tenha sido submetida a violência, que incluam, entre outros, 
medidas de proteção, um julgamento oportuno e o acesso efetivo a tais procedimentos;

g. estabelecer os mecanismos judiciais e administrativos necessários para assegurar que a mulher objeto de violência tenha acesso efetivo a ressarcimento, reparação do dano ou outros meios de compensação justos e eficazes; e

h. adotar as disposições legislativas ou de outra índole que sejam necessárias para efetivar esta Convenção.

A implementação das medidas não trará maiores gastos ao Erário, visto que em grande parcela consistem apenas em orientações às condutas dos atores processuais, sendo aproveitadas as estruturas de depoimento especial já estabelecidas pela Lei 13.431/2017.

\section{Proposta de Projeto de Lei e proposta de enunciado interpretativo ao Código Civil}

Tema: Nulidade de cláusula contratual que viole a igualdade de gênero.

\subsection{Proposta de Projeto de Lei:}

Projeto de Lei XXX, de 2021.

(Do Sr. Deputado X)

Altera a Lei n. ${ }^{\circ} 10.406$, de 10 de janeiro de 2002 - Código Civil, e dá outras providências.

O Congresso Nacional decreta:

Art. $1^{\circ}$ A Lei $n^{\circ} 10.406$, de 10 de janeiro de 2002 (Código Civil), passa a vigorar com as seguintes alterações:

“Art. 113-A. Os atos e cláusulas dos negócios jurídicos que constituam ou causem discriminação em razão do gênero serão considerados nulos e ensejarão responsabilidade por meio de sistema de reparação ou indenização real, eficaz e proporcional ao dano sofrido. (NR)

Art. 424. (...)

Parágrafo único. Considera-se abusiva cláusula contratual que vede a participação do contratante ou que onere sua contraprestação contratual com base no gênero, sendo nula de pleno direito." (NR)

Art. $2^{\circ}$ Esta Lei entra em vigor na data de sua publicação. 


\subsection{Proposta de Enunciado Interpretativo ao Código Civil:}

(Art. 113 do Código Civil). Cláusula contratual que viole a igualdade material de gênero será considerada nula por ofensa à boa-fé objetiva nos negócios jurídicos.

\subsection{Justificativa:}

As medidas apresentadas linhas acima se justificam pelo reconhecimento de que há uma perpetuação da desigualdade material de gênero diante da ausência de norma civil protetiva e repressiva de atos discriminatórios contra a mulher. Sendo assim, afigura-se de todo adequada a sugestão de mudança legislativa que acrescente dispositivo legal que tutele o tema, com base no fundamento constitucional do princípio da isonomia e da dignidade da pessoa humana, tornando possível o verdadeiro equilíbrio na relação contratual.

Cumpre consignar que, na Espanha, a Lei Orgânica nº 03/2007 voltada para a igualdade efetiva de mulheres e homens, conhecida pela sigla LOIEMH, prevê expressamente, em seu artigo 10, que são considerados nulos e sem efeito os atos e cláusulas dos negócios jurídicos que constituam ou causem discriminação por razão de sexo, sendo os causadores do dano civilmente responsáveis pela reparação dos prejuízos. Trata-se de previsão de grande relevo, visto que retira a validade e a eficácia dos negócios jurídicos entabulados, única e exclusivamente em razão de ocasionarem ou representarem conduta discriminatória contra a mulher. Esse dispositivo traz uma nova e relevantíssima função aos negócios jurídicos, traçada pelo direito anti-discriminatório, a que poderíamos chamar de função antidiscriminatória ou função identitária dos contratos, que merece ser prevista expressamente no ordenamento jurídico brasileiro ${ }^{10}$.

\section{Proposta de Projeto de Lei e proposta de enunciado interpretativo ao Código de Processo Civil}

\footnotetext{
${ }^{10}$ HILL, Flávia Pereira. "Uns mais iguais que os outros: em busca da igualdade (material) de gênero no processo civil brasileiro". Revista Eletrônica de Direito Processual. Volume 20. Número 2. Maio-agosto 2019. pp. 201-244.
} 
Tema: Flexibilização do disposto no artigo 53, inciso I, alínea a, do CPC/2015 (competência do foro do domicílio ou residência do guardião de filho incapaz para ação de divórcio, separação, anulação de casamento e reconhecimento ou dissolução de união estável).

\subsection{Proposta de Projeto de Lei:}

Projeto de Lei XXX, de 2021.

(Do Sr. Deputado X)

Altera e reorganiza o inciso I do artigo 53, da Lei no 13.105, de 16 de março de 2015 (Código de Processo Civil), para prever como competente o foro do domicílio da mulher quando, inexistindo interesse de incapazes, for constatada a sua hipossuficiência econômica, nas ações de divórcio, separação, anulação de casamento e reconhecimento ou dissolução de união estável.

O CONGRESSO NACIONAL decreta:

Art. $1^{\circ}$. O artigo 53, I, da Lei nº 13.105, de 16 de março de 2015 (Código de Processo Civil), passa a vigorar com as seguintes alterações:

“Art. 53

I -

a) de domicílio do guardião de filho incapaz;

b) do domicílio da mulher, quando, inexistindo interesse de incapazes, for constatada a sua hipossuficiência econômica.” (NR)

c) do último domicílio do casal, caso não haja filho incapaz;

d) de domicílio do réu, se nenhuma das partes residir no antigo domicílio do casal;

e) de domicílio da vítima de violência doméstica e familiar, nos termos da Lei $n^{\circ}$ 11.340, de

7 de agosto de 2006 (Lei Maria da Penha);”

Art. $2^{\circ}$. Esta Lei entra em vigor na data de sua publicação. 


\subsection{Proposta de Enunciado Interpretativo ao Código de Processo Civil:}

(Art. 53, CPC). Na hipótese de violência doméstica e familiar contra a mulher, a competência para a ação de divórcio, separação, anulação de casamento e reconhecimento ou dissolução de união estável será a do foro do domicílio da mulher, observando-se a disposição do artigo 53, inciso I, alínea 'd' do Código de Processo Civil de 2015, excluindo-se as demais.

\subsection{Justificativa:}

\subsubsection{Justificativa do Projeto de Lei:}

O presente projeto de Lei surge com a finalidade de garantir às mulheres partes hipossuficientes economicamente a facilitação de acesso à justiça e ao Poder Judiciário, nas ações elencadas no artigo 53, inciso I, do Código de Processo Civil de 2015 - sendo estas, a ação de divórcio, separação, anulação de casamento e reconhecimento ou dissolução de união estável.

O artigo 53, inciso I, elenca diversas regras de competência em suas alíneas para as referidas ações, seguindo uma ordem que, pelo entendimento majoritário, é subsidiária, respeitando-se as primeiras, para passar somente depois às competências subsequentes.

Dessa forma, privilegia-se, na alínea 'a' desse inciso, por exemplo, a competência do guardião do filho incapaz, com a finalidade de se proteger a criança ou adolescente incapaz, na medida que a prática dos atos processuais se dará no foro do domicílio do guardião ou guardiã deste.

Ocorre que em determinadas hipóteses, e observada a situação fática brasileira, na qual, em que pese a inserção e a paulatina ascensão das mulheres no mercado de trabalho e a flexibilização dos espaços públicos e privados, bem como o reconhecimento da igualdade entre homens e mulheres no aspecto formal, ainda se observa a desigualdade de gênero em seu aspecto material ou substancial, que tem seus reflexos na vida das mulheres, obstando a concretização e o acesso a seus direitos mais fundamentais, dentre estes o direito de acesso à justiça. Nesse cenário, as mulheres podem vir a ser prejudicadas diante de sua 
vulnerabilidade processual, como nos casos em que a parte mulher é hipossuficiente economicamente, mormente em comparação com a parte adversa, e nas ações de violência doméstica e familiar.

Ademais, as hipóteses trazidas no artigo 53, inciso I, a partir da alínea 'b', não são regidas por critérios subjetivos, isto é, que observam a condição da parte litigante para definição da competência, visto que, na alínea 'a', que prevê como foro competente o do domicílio do guardião de filho incapaz, objetiva a proteção do interesse do menor.

Por outro lado, os critérios elencados nas alíneas 'b' e 'c' são meramente objetivos, dado que, para definição da competência, considera-se o último local do domicílio do casal e, se nenhum viver neste, o domicílio do réu, o que não se afigura razoável em determinadas situações, nas quais podem existir desigualdades entre as partes litigantes, capazes de acarretar severo desnível e comprometer o acesso à justiça, a isonomia e a paridade de armas.

Isto porque as mencionadas alíneas (' $b$ ' e 'c') pressupõem uma igualdade processual entre as partes considerando-as em abstrato para definição da competência, o que, em determinadas situações, pode acarretar prejuízo às mulheres hipossuficientes economicamente, na medida em que, quando consideradas iguais sem observância do caso concreto, podem vir a sofrer discriminações ou óbices ao acesso a seus direitos, isto é, se observado o caso abstratamente, o tratamento igualitário, ao invés de beneficiar, poderá gerar desigualdade discriminatória, de modo que, em tese, não se justificaria a fixação diferenciada de competência, mas, bem vistas as coisas, em prol da igualdade material no processo, avulta a necessidade da fixação da competência no foro do domicílio da mulher, nos casos que demonstrada sua hipossuficiência econômica e inexistente interesse de incapaz.

Como aponta Fernanda Tartuce ${ }^{11}$ :

"O problema inicia-se a partir da alínea b: caso não haja filhos incapazes (...). Neste ponto, o dispositivo dever ser criticado. Inserir um critério diferente do gênero do cônjuge, qual seja a guarda do filho incapaz é importante para corrigir uma distorção na aplicação do critério. Por outro lado, ignorar que, na maioria dos casos a mulher ainda é o elo mais fraco da relação, mesmo sem a presença de filhos menores, é desconhecer a realidade brasileira".

\footnotetext{
${ }^{11}$ TARTUCE, Fernanda. Vulnerabilidade processual no Novo CPC. Disponível em: <http://www. fernandatartuce.com.br/wp-content/uploads/2016/01/Vulnerabilidade-no-NCPC.pdf $>$. p. 21 Acesso em 25/08/2021.
} 
Ainda, ensina Ricardo Ferracini Neto ${ }^{12}$ :

"A igualdade material exige o tratamento igual ao que é igual e desigual ao que se coloca em tal desequilíbrio em relação aos demais indivíduos. Indivíduos em situação de igualdade, assim, não poderão receber tratamentos diferenciados, sob pena de caracterização de atuação arbitrária por parte de quem realiza a discriminação. A indicação do arbítrio, por sua vez, deve estar ligada a um

"'fundamento material ou critério material objetivo"".

Por esta razão, diante dos fundamentos trazidos, justifica-se a inserção da alínea 'e' no artigo 53, inciso I, do Código de Processo Civil de 2015, para prever como foro competente nas ações de divórcio, separação, anulação de casamento e reconhecimento ou dissolução de união estável o da mulher quando constatada sua hipossuficiência econômica.

Com estas considerações, afigura-se de todo recomendável a aprovação do presente Projeto de Lei, que traz alteração importante à redação da Lei n. 13.105, de 16 de março de 2015, Código de Processo Civil.

\subsubsection{Justificativa do Enunciado:}

A igualdade entre homens e mulheres é prevista no art. $5^{\circ}$, caput, da Constituição Federal de 1988 e em diversos tratados internacionais que o Brasil é signatário, como a Declaração Internacional de Direitos humanos, o Pacto de São José da Costa Rica e a Convenção Interamericana para Prevenir, Punir e Erradicar a Violência Contra a Mulher. Entretanto, ainda é necessária a adaptação da prática forense às especificidades e diferenciações biológicas existentes entre os gêneros, bem como com a proteção às mulheres vítimas de violência doméstica.

Na mesma toada, em decorrência direta da aplicação dos princípios constitucionais e dos tratados supracitados, considera-se adequada a proposta de enunciado que lastreie Magistrados, advogados, membros do Ministério Público e da Defensoria Pública para lidar de forma mais adequada ao caso concreto no que concerne aos casos de violência doméstica contra a mulher, oportunizando, por exemplo, flexibilizar o foro de competência na ação de divórcio, separação, anulação de casamento e reconhecimento ou dissolução de união

\footnotetext{
${ }^{12}$ NETO, Ricardo Ferracini, A violência doméstica contra a mulher e a transversalidade de gênero. Salvador: Juspodivm, 2018. p. 175. Acesso em 25/08/2021.
} 
estável, em caso de interesse de vítima de violência doméstica, vulnerável na relação sub judice.

Por fim, importante ressaltar que a presente proposta de enunciado está de acordo com as recomendações contidas no Relatório 54/01 (caso 12.054, Maria da Penha) da Comissão Interamericana de Direitos Humanos, especialmente a que determina intensificar o processo de reforma que evite a tolerância estatal e o tratamento discriminatório com respeito à violência doméstica contra mulheres no Brasil.

\section{Conclusão}

As proposições apresentadas vêm ao encontro da necessidade de erradicação de qualquer forma de desigualdade existente entre homens e mulheres e, por que não, para reequilibrar a relação entre vulneráveis e não vulneráveis.

Não à toa, em diversos tópicos das propostas apresentadas, em que pese o foco do trabalho ser a erradicação da desigualdade de gênero, foi necessário superar a polarização homem $\mathrm{x}$ mulher para se chegar a um texto que abrangesse pessoas que não são contempladas de maneira satisfatória no ambiente processual civil contemporâneo.

Isso demonstra que o processo precisa cada vez ser mais humanizado, voltado à realização da justiça material, mas criando condições de participação dos excluídos, sob pena de o conceito de Justiça ser sempre algo pertencente aos privilegiados, àqueles que não encontram dificuldades, barreiras para o exercício do direito de ação e para as demais etapas de uma demanda jurisdicional.

Se o processo é meio de concretização da justiça e se perfaz com a intervenção do Estado-juiz com vistas a solucionar e pacificar conflitos, as partes devem ter condições de litigar sem quaisquer óbices, caso contrário, “o jogo” estará desequilibrado mesmo antes de seu início. Aliás, no que tange à questão da desigualdade de gênero, por um sem número de fatores anteriores à realidade processual, já há um desequilíbrio enorme da relação homem x mulher, mesmo quando em números absolutos ela representam não só a maioria da sociedade, mas parte considerável das chefes de família. ${ }^{13}$

${ }^{13}$ INSTITUTO DE PESQUISA ECONÔMICA APLICADA. Tabela 2.2.a. Distribuição percentual das famílias, por tipo de arranjo familiar, segundo o sexo do(a) chefe de família. Brasil, 1995 a 2015. Disponível em http://www.ipea.gov.br/retrato/indicadores_chefia_familia.html. Acesso em 25/08/2021. 
Embora se origine de um grupo de pesquisa, os autores do presente trabalho não se contentaram em restringir as suas atividades a trocas de ideias ou estudos teóricos puros. Diante da premência do tema, optou-se por se retirar da zona de conforto do pesquisador e sair a campo para cunhar propostas concretas que sejam aptas a, unindo teoria e prática, realizar mudanças que são consideradas operacionalmente simples, porém profundamente paradigmáticas.

O presente trabalho se oferece, portanto, com uma contribuição de vários pesquisadores, oriundos de diferentes regiões do Brasil e com experiências plurais no nosso sistema de justiça, com vistas a plantar sementes de um Direito Processual Civil pátrio que condiga, em sua realidade concreta, com os ideais que nos são mais caros, dentre os quais, especialmente, o da genuína igualdade e que dê frutos portentosos para esta e para as gerações futuras de jurisdicionados brasileiros.

Oxalá esse futuro esteja próximo e a colheita seja farta para todos, indistintamente!

\section{REFERÊNCIAS}

ANDRIGHI, Nancy. MAZZOLA, Marcelo. Reflexões sobre a igualdade de gênero no processo civil. Disponível no endereço eletrônico: https://www.conjur.com.br/2019abr-29/opiniao-reflexoes-igualdade-genero-processo-civil Consulta realizada em $30 / 04 / 2019$.

BARBOSA. Thais da Silva. $O$ tratamento probatório nas ações de divulgação não consensual de imagens íntimas no processo civil brasileiro. Dissertação de mestrado apresentada ao Programa de Pós-Graduação Stricto Sensu em Direito e Inovação da Universidade Federal de Juiz de Fora. Juiz de Fora. 2018.

CAPONI, Remo. "Rigidez e flexibilidade do processo ordinário de cognição". Revista Eletrônica de Direito Processual. Ano 10. Volume 17. Número 2. Julho a dezembro de 2016. pp. 531-549.

CONFERÊNCIA MUNDIAL SOBRE DIREITOS HUMANOS DE 1993 . Declaração $e$ Programa de Ação de Viena, Viena, 14-25 de Junho de 1993. Disponível no endereço eletrônico: 
Revista Eletrônica de Direito Processual - REDP.

Rio de Janeiro. Ano 15. Volume 22. Número 3. Setembro a Dezembro de 2021

Periódico Quadrimestral da Pós-Graduação Stricto Sensu em Direito Processual da UERJ

Patrono: José Carlos Barbosa Moreira (in mem.). ISSN 1982-7636. pp. 1149-1191 www.redp.uerj.br

https://www.oas.org/dil/port/1993\%20Declara\%C3\%A7\%C3\%A3o\%20e\%20Progra ma\%20de\%20Ac\%C3\%A7\%C3\%A3o\%20adoptado\%20pela\%20Confer\%C3\%AAn cia\%20Mundial\%20de\%20Viena\%20sobre\%20Direitos\%20Humanos\%20em\%20ju nho\%20de\%201993.pdf Consulta realizada em 02/06/2019.

CONSELHO NACIONAL DE JUSTIÇA. Índice de Acesso à Justiça. 2021.

CONSELHO NACIONAL DE JUSTIÇA. CNJ abre procedimento sobre a conduta de juiz em caso de Mariana Ferrer. Disponível em https://www.cnj.jus.br/cnj-abreprocedimento-sobre-conduta-de-juiz-em-caso-de-mariana-ferrer/. Acesso em 25/08/2021.

ESTADOS UNIDOS DO BRASIL. Código Civil, de 01 de janeiro de 1916. Disponível em http://www.planalto.gov.br/ccivil_03/leis/13071.htm. Acesso em 25/08/2021.

DEFENSORIA PÚBLICA GERAL DO ESTADO DO RIO DE JANEIRO. Recomendações e enunciados da Defensoria Pública sobre mediação e conciliação. Disponível no endereço eletrônico: http://www.defensoria.rj.def.br/uploads/arquivos/a67c94da9fff4cf8bb11f92b41976d 19.pdf. Consulta realizada em 04/06/2019.

DIDIER JUNIOR, Fredie. "O princípio da cooperação: uma apresentação". Revista de Processo. ano 30. N. 127. Setembro de 2005. pp. 75-79.

DUARTE, Márcia Michele Garcia. Tirania no próprio ninho: violência doméstica e direitos humanos da mulher. Motivos da violência de gênero, deveres do Estado e propostas para o enfrentamento efetivo. Santa Cruz do Sul: Essere nel Mondo. 2015.

FERRACINI NETO, Ricardo, A violência doméstica contra a mulher e a transversalidade de gênero. Salvador: Juspodivm, 2018, p. 175. Acesso em 25/08/2021.

FISS, Owen. “A Morte do Direito?”. Direito Como Razão Pública. Processo, Jurisdição e Sociedade. 2. Ed. Curitiba: Juruá. 2017.

FÓRUM PERMANENTE DE PROCESSUALISTAS CIVIS. Enunciados aprovados. Disponível no endereço eletrônico: https://institutodc.com.br/wpcontent/uploads/2017/06/FPPC-Carta-de-Florianopolis.pdf Consulta realizada em 01/06/2019. 
GRECO, Leonardo. "Contraditório efetivo". Revista Eletrônica de Direito Processual. Volume 15. Janeiro-junho 2015. pp. 299-310.

GUARNIERI, Thatiana Haddad. "O direito das mulheres no contexto internacional: da criação da ONU (1945) à Conferência de Beijing (1995)”. In Revista Eletrônica da Faculdade Metodista Granbery. N.8. Jan-Jun 2010. pp. 01-28.

HILL, Flávia Pereira. "Uns mais iguais que os outros: em busca da igualdade (material) de gênero no processo civil brasileiro". Revista Eletrônica de Direito Processual. Volume 20. Número 2. Maio-agosto 2019. Pp. 201-244.

IGUALDADE. In: Dicionário Online de Português. Porto: 7Graus, 2020. Disponível em https://www.dicio.com.br/igualdade/. Acesso em 25/08/2021.

INSTITUTO DE PESQUISA ECONÔMICA APLICADA. Tabela 2.2.a. Distribuição percentual das famílias, por tipo de arranjo familiar, segundo o sexo do(a) chefe de família. Brasil, 1995 a 2015. Disponível em http://www.ipea.gov.br/retrato/indicadores_chefia_familia.html. Acesso em 25/08/2021.

MIGALHAS. TJ/SP libera vítima de violência de comparecer a audiência de conciliação de divórcio. Disponível no endereço eletrônico: https://www.migalhas.com.br/Quentes/17,MI253270,71043-

$\underline{\text { TJSP+libera+vitima+de+violencia+de+comparecer+a+audiencia+de }}$ Consulta realizada em 05/06/2019.

MIGALHAS. TJSE dispensa gestantes de passar por detector de metais nas dependências da Corte. Decisão do presidente da Corte se estende a grávidas servidoras ou não. Publicado em 16 de outubro de 2019. Disponível em https://migalhas.uol.com.br/quentes/313163/tj-se-dispensa-gestantes-de-passar-pordetector-de-metais-nas-dependencias-da-corte

MIGALHAS. Ato do TJ/PB dispensa advogadas gestantes de passarem por detectores de metais. Norma dispõe sobre necessidade de comprovação da gestação para que seja permitida a entrada sem uso do aparelho. Publicado em 29 de julho de 2019. Disponível em https://migalhas.uol.com.br/quentes/307553/ato-do-tj-pb-dispensaadvogadas-gestantes-de-passarem-por-detectores-de-metais. 
MITIDIERO, Daniel. A Colaboração como Modelo e como Princípio no Processo Civil. Disponível no endereço eletrônico: https://www.academia.edu/10250562/Coopera\%C3\%A7\%C3\%A3o_como_Modelo e_como_Princ\%C3\%ADpio_no_Processo_Civil Consulta realizada em 31/07/2018.

MOREIRA, José Carlos Barbosa. “Por um processo socialmente efetivo”. Temas de Direito Processual. Oitava Série. São Paulo: Saraiva. pp. 15-27.

MUÑÓZ, Soledad García. "Género y derechos humanos de las mujeres: estândares conceptuales y normativos em clave de derecho internacional". PARCERO, Juan A. Cruz. VÁZQUEZ, Rodolfo (Coords). Derechos de las mujeres en el Derecho Internacional. pp. 47-84.Disponível no endereço eletrônico: https://www.scjn.gob.mx/sites/default/files/igualdad/libros/documento/201612/Derechos-de-las-mujeres.pdf Consulta realizada em 02/06/2019.

\section{ORGANIZAÇÃO DAS NAÇOES UNIDAS. DEPARTAMENTO DE ASSUNTOS} ECONÔMICOS E SOCIAIS. ASSESSORIA ESPECIAL EM TEMAS DE GÊNERO E AVANÇO DAS MULHERES. Concepts and definitions. Disponível no endereço eletrônico: $\quad$ https://www.un.org/womenwatch/osagi/conceptsandefinitions.htm Consulta realizada em 03/06/2019.

ORGANIZAÇÃO DAS NAÇÕES UNIDAS. IV Conferência Mundial sobre as Mulheres. Declaração e Plano de Ação. Disponível no endereço eletrônico: http://www.onumulheres.org.br/wp-content/uploads/2014/02/declaracao_pequim.pdf Consulta realizada em 02/06/2019.

PARIZOTTO, Natália Regina. "Violência doméstica de gênero e mediação de conflitos: a reatualização do conservadorismo”. Serv. Soc. Soc., São Paulo, n. 132, p. 287-305, maio/ago. 2018. pp. 300-301.

PINHO, Humberto Dalla Bernardina de. ALVES, Tatiana Machado. "A cooperação no novo Código de Processo Civil: desafios concretos para sua implementação". Revista Eletrônica de Direito Processual. Ano 8. Volume 15. Janeiro a junho 2015. pp. 240267. 
PUIVERT, Silvia. "El principio de igualdad de género y el derecho antidiscriminatorio". In PICOT I JUNOY, Joan (Org). Principios y garantias procesales. Barcelona: Bosch Procesal. 2013. pp. 289-299.

REINO DA ESPANHA. Constitución Española, aprobada en 31 de octubre de 1978. Disponível, em espanhol, no endereço eletrônico: https://boe.es/legislacion/documentos/ConstitucionCASTELLANO.pdf Consulta realizada em 02/06/2019.

REINO DA ESPANHA. Ley Orgánica 3/2007, de 22 de marzo, para la igualdad efectiva de mujeres y hombres. Disponível, em espanhol, no endereço eletrônico: Ley Orgánica 3/2007, de 22 de marzo, para la igualdad efectiva de mujeres y hombres. Disponível no endereço eletrônico: https://www.boe.es/buscar/pdf/2007/BOE-A-2007-6115consolidado.pdf Consulta realizada em 02/06/2019.

REPÚBLICA FEDERATIVA DO BRASIL. Estatuto da Mulher Casada, de 27 de agosto de 1962. Disponível em http://www.planalto.gov.br/ccivil_03/leis/19501969/14121.htm. Acesso em 25/08/2021.

REPÚBLICA FEDERATIVA DO BRASIL. Lei Federal nº 6.515, de 26 de dezembro de 1977. Disponível em http://www.planalto.gov.br/ccivil_03/leis/16515.htm. Acesso em 25/08/2021.

REPÚBLICA FEDERATIVA DO BRASIL. Constituição da República Federativa do Brasil, de 05 de outubro de 1988. Disponível em http://www.planalto.gov.br/ccivil_03/constituicao/constituicao.htm. Acesso em 25/08/2021.

REPÚBLICA FEDERATIVA DO BRASIL. Lei n 8.906, de 4 de julho 1994. Disponível em <http://www.planalto.gov.br/ccivil_03/leis/18906.htm>. Acesso em 25/08/2021.

REPÚBLICA FEDERATIVA DO BRASIL. Lei no 10.406, de 10 de janeiro de 2002.

Disponível

em http://www.planalto.gov.br/ccivil_03/leis/2002/L10406compilada.htm. Acesso em 25/08/2021. 
REPÚBLICA FEDERATIVA DO BRASIL. Decreto nº 4.377, de 13 de setembro de 2002.

Disponível em http://www.planalto.gov.br/ccivil_03/decreto/2002/d4377.htm. Acesso em 25/08/2021.

REPÚBLICA FEDERATIVA DO BRASIL. Lei $\mathrm{n}^{\circ}$ 11.340, de 7 de agosto de 2006. Disponível em http://www.planalto.gov.br/ccivil_03/_ato20042006/2006/lei/111340.htm. Acesso em 25/08/2021.

REPÚBLICA FEDERATIVA DO BRASIL. Código de Processo Civil, de 16 de março de 2015. Disponível em http://www.planalto.gov.br/ccivil_03/_ato20152018/2015/lei/113105.htm. Acesso em 25/08/2021.

REPÚBLICA FEDERATIVA DO BRASIL. Lei $\mathrm{n}^{\circ}$ 13.140, de 26 de junho de 2015. Disponível em http://www.planalto.gov.br/ccivil_03/_ato20152018/2015/lei/113140.htm. Acesso em 25/08/2021.

REPÚBLICA FEDERATIVA DO BRASIL. Lei nº 13.363, de 25 de novembro de 2016. Disponível em http://www.planalto.gov.br/ccivil_03/_ato20152018/2016/lei/113363.htm. Acesso em 25/08/2021.

REPÚBLICA FEDERATIVA DO BRASIL. Lei $\mathrm{n}^{\circ}$ 14.022, de 7 de julho de 2020. Disponível em http://www.planalto.gov.br/ccivil_03/_ato20192022/2020/lei/L14022.htm. Acesso em 25/08/2021.

RESNIK, Judith. "Comparative (in)equalities: CEDAW, the jurisdiction of gender, and the heterogeneity of transnational law production". International Journal of Constitutional Law, Oxford University Press. Volume 10, Issue 2, 30 March 2012. pp. 531-550.

SCAVONE, Lucila. A maternidade e o feminismo: diálogo com as ciências sociais. Disponível no endereço eletrônico: http://www.scielo.br/pdf/cpa/n16/n16a08.pdf Consulta realizada em 01/06/2019.

SUPERIOR TRIBUNAL DE JUSTIÇA. $3^{\mathrm{a}}$ Turma. Recurso especial $\mathrm{n}^{\mathrm{o}}$ 1.060.168/AC. Relatora Ministra Nancy Andrighi. Julgado em 25/08/2009.

SUPERIOR TRIBUNAL DE JUSTIÇA. $3^{\text {a }}$ Turma. Recurso Especial $n^{\circ}$ 270.730/RJ. Relatora para acórdão Min. Nancy Andrighi. Julgado em 19/12/2000. 
SUPERIOR TRIBUNAL DE JUSTIÇA. $4^{\text {a }}$ Turma. Agravo interno no Agravo em Recurso Especial no 774.270/RS. Relator Ministro Raul Araújo. Decisão unânime. Julgado em 02/05/2017.

TARTUCE, Fernanda. Vulnerabilidade processual no Novo CPC. Disponível em http://www.fernandatartuce.com.br/wp-content/uploads/2016/01/Vulnerabilidadeno-NCPC.pdf>. p. 21. Acesso em 25/08/2021.

TRIBUNAL DE JUSTIÇA DO ESTADO DE RORAIMA. Resolução $n^{o}$ 10/2016. Disponível no endereço eletrônico: http://www.tjrr.jus.br/legislacao/phocadownload/Resolucoes/Tribunal-

Pleno/2016/res.\%2010-2016.pdf Consulta realizada em 01/06/2019.

UNIÃO EUROPEIA. Carta dos Direitos Fundamentais da União Europeia. Disponível no endereço eletrônico: https://eur-lex.europa.eu/legalcontent/PT/TXT/PDF/?uri=CELEX:12012P/TXT\&from=EN Consulta realizada em 03/06/2019.

WAMBIER, Luiz Rodrigues. "O modelo processual cooperativo e a flexibilização procedimental". Revista Eletrônica de Direito Processual. Ano 11. Volume 18. Número 3. Setembro a dezembro de 2017. pp. 238-255. 